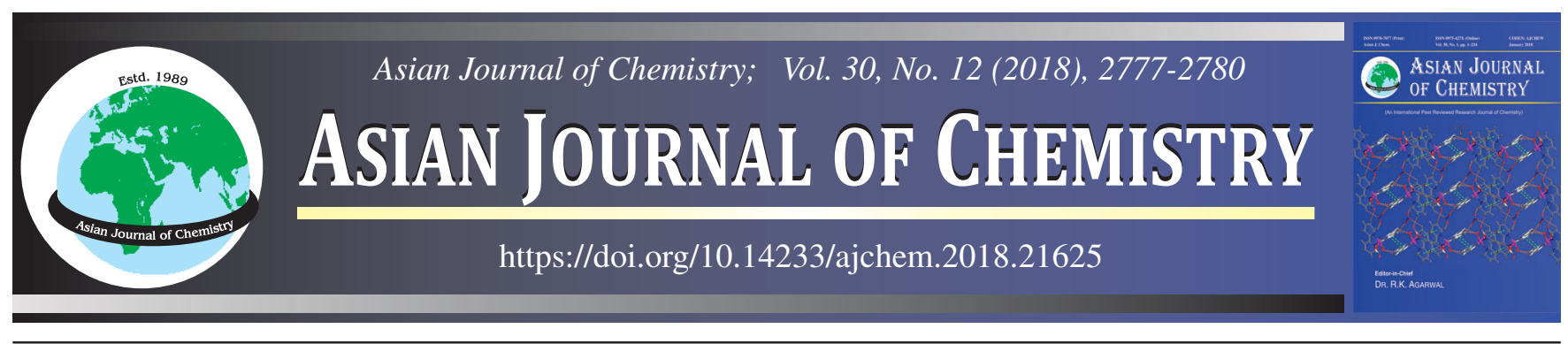

\title{
"Side-Off"'-Schiff Base Copper Complexes: Synthesis, Characterization and Cytotoxic Activity in A549 Cell Line
}

\author{
S.H. AnJana LaKShmi* and K. Pandian
}

Department of Inorganic Chemistry, School of Chemical Sciences, University of Madras, Maraimalai Campus, Guindy, Chennai-600 025, India

*Corresponding author: Tel: +91 44 22202795, E-mail: anjanalakshmi.chem@gmail.com

Received: 1 August 2018;

Accepted: 29 September 2018;

Published online: 31 October 2018;

AJC-19147

A unique series of binuclear "Side-off" Schiff base copper complexes, viz. complex A, B and $\mathbf{C}$ were synthesized and characterized by the
optical physical probes and further, in vitro cytotoxic activity of the complexes was evaluated on A549 lung carcinoma cell line. The metal
complexes were dissolved in DMSO at various concentrations $(1000,500,250,100,50,25,10,5$ and $2.5 \mu \mathrm{M})$ of each compound were
prepared for exposure to A549 cell line. MTT-Cell viability assay was performed to assess the cytotoxicity of the compounds. Out of three
copper complexes synthesized in this study, compound C exhibited notable cytotoxic effects in human lung (A549) cancer cell lines after
$24 \mathrm{~h}$ treatment. Further investigations on the precise mechanism of action are underway to achieve a better understanding over the
cytotoxicity mechanism.

Keywords: Schiff base, Copper complexes, Cytotoxicity, Cancer cell line.

\section{INTRODUCTION}

One of the impending approaches in anticancer chemistry is focused on the design of new metal compounds increase cytotoxicity, unambiguously to cancer cells. In this framework, the extensive range of coordination numbers, geometries, redox states, thermodynamic, kinetic features and the inherent properties of cationic metal ion and ligand itself provides the medicinal chemist an ample spectrum of reactivity. The science of bioinorganic chemistry involving the synthesis and biological investigation of inorganic complexes is gaining impetus [1-6]. In this regard, Schiff bases and their metal complexes have been studied for their interesting and important properties such as their ability to bind reversibly to oxygen, catalytic property, amino group transfer, photochromicity and complex formation [7]. Schiff bases ligands coordinate with metal ions via azomethine nitrogen. They have been studied extensively because of increasing recognition of their role in biological system. Schiff bases act as superior chelating agents for transition and nontransition metal groups and exhibit remarkable biological activities [8]. Coordination of these compounds with metal ions, such as copper and nickel enhance their biological activities.
Studies have shown that the metal complexes of Schiff's base ligands have better antimicrobial and anticancer activities as compared to Schiff's bases [9]. Copper compounds have been investigated in detail owing to the assumption that endogenous metals may be less toxic [10]. Further, copper complexes are being extensively studied for their application such as antibacterial, antifungal, anti-inflammatory and antitumor agents [11]. Copper complexes have been reported to exhibit biological activities such as DNA damage, Single-strand breaks in super coiled plasmid DNA in vitro, strong anti-proliferative activity, production of ROS, cell death by non-apoptotic mode, changes in redox potential, inhibition of cell cycle, etc. in various cell lines including A549 lung carcinoma cell line [12-15]. Copperbased complexes have been reported to exhibit anti-neoplastic potency in various cell lines including human ovarian carcinoma (CH1), murine leukemia (L1210) and various cervico-uterine carcinomas. Such effects of copper complexes are on par or even exceeding the effects exhibited by cisplatin [16-18].

With this background, herein, we have synthesized three copper(II) complexes of Schiff base. The structure of the complexes was determined and in vitro cytotoxic activity of the complexes was assessed on A549 lung carcinoma cell line.

This is an open access journal, and articles are distributed under the terms of the Creative Commons Attribution-NonCommercial 4.0 International (CC BY-NC 4.0) License, which allows others to copy and redistribute the material in any medium or format, remix, transform, and build upon the material, as long as appropriate credit is given and the new creations are licensed under the identical terms. 


\section{EXPERIMENTAL}

Copper(II) perchlorate hexahydrate, 1,4-diaminocyclohexane were purchased from Aldrich, acetonitrile, ethanol, methanol and diethyl ether were purchased from SRL (India). Copper(II) acetate dihydrate were purchased from Qualigens Mumbai (India), dimethyl sulphoxide, hydrochloric acid, sulphuric acid, $p$-cresol, paraformaldehyde, perchloric acid and chloroform were purchased from S.D. Fine Chemicals, Mumbai (India). The A549 cell line was obtained from the American Type Culture Collection (ATCC) Rockville, MD, USA. Culture media, antibiotics, MTT were purchased from Sigma, USA.

The solvents were purified by following standard procedures. The commercial grade methanol and ethanol were refluxed for $6 \mathrm{~h}$ with lime and distilled the middle fraction was collected and used. The commercial grade acetonitrile was refluxed at $80{ }^{\circ} \mathrm{C}$ with $\mathrm{P}_{2} \mathrm{O}_{5}$ for $6 \mathrm{~h}$. The clear distillate was collected and stored over molecular sieves.

The $\mathrm{C}, \mathrm{H}, \mathrm{N}$ contents of the ligands and complexes were carried out using a Carlo Erba Elemental analyzer Model 1106. The IR spectra were recorded on Perkin Elmer FTIR, spectrometer with samples prepared as $\mathrm{KBr}$ Pellets. UV-visible spectra were recorded using a Perkin Elmer Lambda 35 spectrophotometer operating in the range of 200-1100 nm with quartz cells and $\varepsilon$ are given in $\mathrm{M}^{-1} \mathrm{~cm}^{-1}$. Electrospray ionization mass spectral measurements were done using Thermo Finnigan LCQ6000 Advantages Max-ESI mass spectrometer. The metal complexes were dissolved in DMSO at various concentrations $(1000,500,250,100,50,25,10,5$ and $2.5 \mu \mathrm{M})$ of each compound were prepared for exposure to A549 cell line.

Synthesis of unsymmetrical binuclear side-off $\mathbf{C u}(\mathrm{II})$ complexes: The unsymmetrical binuclear side-off $\mathrm{Cu}$ (II) complexes (A, B and $\mathbf{C}$ ) were prepared from a general synthetic procedure in which, the vigorously stirred suspension of mononuclear complex [CuL] (synthesized by reacting 2,4-diformylmethylphenol, 1,4-diamino cyclohexane and copper acetate monohydrate at room temperature in the ratio of $2: 1: 1)(1 \mathrm{mmol})$ in methanol, a methanolic solution of $\mathrm{Cu}\left(\mathrm{ClO}_{4}\right)_{2} \cdot 6 \mathrm{H}_{2} \mathrm{O}(1 \mathrm{mmol})$ was added slowly drop-wise and the mixture was stirred for 15 min to obtain a clear solution. Then the methanolic solution (10 $\mathrm{mL})$ of corresponding amine $(0.18 \mathrm{~g}$, aniline; $0.20 \mathrm{~g}$, benzylamine; $0.28 \mathrm{~g}$ 1-naphthyleneamine; $2 \mathrm{mmol}$ ) was added dropwise to the above solution and refluxed for $2 \mathrm{~h}$. A resulting solid was separated on evaporating the solution at room temperature and the resulting compound was washed with ether and dried.

Elemental analysis (\%) for $\mathrm{C}_{36} \mathrm{H}_{34} \mathrm{~N}_{4} \mathrm{O}_{2} \mathrm{Cu}_{2}$ (complex A) calculated (found) \%: C 63.42 (63.11); H 5.03 (4.85); N 8.22 (8.05). Selected IR (KBr pellet, $\left.v_{\max }, \mathrm{cm}^{-1}\right): 3431$ [br, $\left.v(\mathrm{OH})\right]$, $1634[\mathrm{~s}, \mathrm{v}(\mathrm{C}=\mathrm{N})], 1102 \mathrm{vs}, 622 \mathrm{~s},\left[\mathrm{v}\left(\mathrm{ClO}_{4}^{-}\right)\right]$. UV-visible $\lambda_{\max }$ (nm) $\left(\varepsilon, \mathrm{M}^{-1} \mathrm{~cm}^{-1} \mathrm{dm}^{3}\right): 226(3,28,000) ; 305(63,000)$ and $571(34)$.

Elemental analysis (\%) for $\mathrm{C}_{38} \mathrm{H}_{38} \mathrm{~N}_{4} \mathrm{O}_{2} \mathrm{Cu}_{2}$ (complex B) calculated (found) \%: C 64.30 (64.12); H 5.40 (5.03); N 7.89 (7.22). Selected IR ( $\mathrm{KBr}$ pellet, $\left.v_{\max }, \mathrm{cm}^{-1}\right): 3422$ [br, $\left.\mathrm{v}(\mathrm{OH})\right]$, $1639[\mathrm{~s}, \mathrm{v}(\mathrm{C}=\mathrm{N})] 1112$ and $1088 \mathrm{vs}, 626 \mathrm{~s},\left[\mathrm{v}\left(\mathrm{ClO}_{4}^{-}\right)\right]$. UV-visible $\lambda_{\max }(\mathrm{nm})\left(\varepsilon, \mathrm{M}^{-1} \mathrm{~cm}^{-1} \mathrm{dm}^{3}\right): 209$ (3,06,000); $260(1,33,000)$ and 596 (42).

Elemental analysis (\%) for $\mathrm{C}_{44} \mathrm{H}_{38} \mathrm{~N}_{4} \mathrm{O}_{2} \mathrm{Cu}_{2}$ (complex C); calculated (found) \%: C 67.59 (67.42), H 4.90 (4.03), N 7.17
(7.02). Selected IR (KBr pellet, $\left.v_{\max }, \mathrm{cm}^{-1}\right): 3440$ [br, $\left.v(\mathrm{OH})\right]$, $1627[\mathrm{~s}, \mathrm{v}(\mathrm{C}=\mathrm{N})], 1111$ and $1088 \mathrm{vs}, 629 \mathrm{~s},\left[\mathrm{v}\left(\mathrm{ClO}_{4}^{-}\right)\right]$. UV-visible $\lambda_{\max }(\mathrm{nm})\left(\varepsilon, \mathrm{M}^{-1} \mathrm{~cm}^{-1} \mathrm{dm}^{3}\right): 213(3,39,000) ; 281(1,52,000)$ and 622 (49).

The in vitro cytotoxicity of three copper complexes was assessed in A549 cell line (ATCC, USA). The cell line was maintained on Dulbecco's Minimum Essential Medium (DMEM) supplemented with $10 \%$ fetal calf serum. A sub-confluent monolayer of the cell line was trypsinized and $1 \times 10^{5}$ cells were seeded in each well of a 96 well plate. One plate was used for each metal complexes. Control wells were prepared by addition of culture medium without the compounds. The plates were incubated at $37^{\circ} \mathrm{C}$ in a $5 \% \mathrm{CO}_{2}$ incubator for $24 \mathrm{~h}$. The plates were incubated at $37^{\circ} \mathrm{C}$ for $24 \mathrm{~h}$ (cells reach confluence in the plate during this time). At $24 \mathrm{~h}$, the cells were treated with various concentrations $(1000,500,250,100,50,25,10$, 5 and $2.5 \mu \mathrm{M}$ ) of metal complexes and incubated for a period of $24 \mathrm{~h}$ [19-25]. Upon completion of the incubation, MTT dye solution was added to each well to a final concentration of $5 \mathrm{mg} / \mathrm{mL}$. [3-(4,5-Dimethylthiazol-2-yl)-2,5-diphenyltetrazolium bromide (MTT) cell viability assay was performed to assess the cytotoxicity of compounds. The MTT assay for cell injury is based on the ability of mitochondrial dehydrogenases of viable cells to reduce MTT to an insoluble purple formazan product which can be quantified spectrophotometrically. This formazan production is proportionate to the viable cell number and inversely proportional to the degree of cytotoxicity. After $4 \mathrm{~h}$ incubation, the culture media were discarded and the wells were washed with phosphate buffer saline, followed by addition of DMSO and subsequent incubation for $0.5 \mathrm{~h}$. The optical density of each well was then a microplate reader at a wavelength of $540 \mathrm{~nm}$. The $\mathrm{IC}_{50}$ values were determined by plotting the percentage viability versus concentration on a logarithmic graph and reading off the concentration at which $50 \%$ of cells remained viable relative to the control. Each experiment was repeated at least three times to obtain mean values.

\section{RESULTS AND DISCUSSION}

Infrared analysis: The IR spectra of unsymmetrical macrocyclic binuclear $\mathrm{Cu}$ (II) complexes (A, B and $\mathbf{C}$ ) displayed a distinctive peak around $3400 \mathrm{~cm}^{-1}$, which contributes to $-\mathrm{OH}$ group stretching vibration (Fig. 1). The disappearance of carbonyl stretching frequency from mononuclear complex and presence of a strong band around the range of 1639-1621 cm is designated to $v(\mathrm{C}=\mathrm{N})$ vibration of binuclear Schiff base complexes. The peak at 1100 and $620 \mathrm{~cm}^{-1}$ could be owing to antisymmetric stretch and bending peak of perchlorate ions. The perchlorate ions have not revealed splitting peaks in the region around $1100 \mathrm{~cm}^{-1}$ owing to perchlorate ion were uncoordinated to the $\mathrm{Cu}(\mathrm{II})$ ions.

Electronic spectral analysis: The electronic spectra of complexes (A, B and $\mathbf{C}$ ) have been observed (Fig. 2) in the range 200-1000 $\mathrm{nm}$ in acetonitrile. The absorption spectra of all the three copper complexes exhibit three main features, one or more intense peaks below $300 \mathrm{~nm}$ consigned to the intra-ligand charge-transfer transition. Further, prepared complexes showed that on moving from the complexes $\mathbf{A}$ to $\mathbf{B}$ to $\mathbf{C}$, an increase in $\lambda_{\max }$ (red shift) of the $d$ - $d$ transition of $\mathrm{Cu}$ (II) ion was observed. 

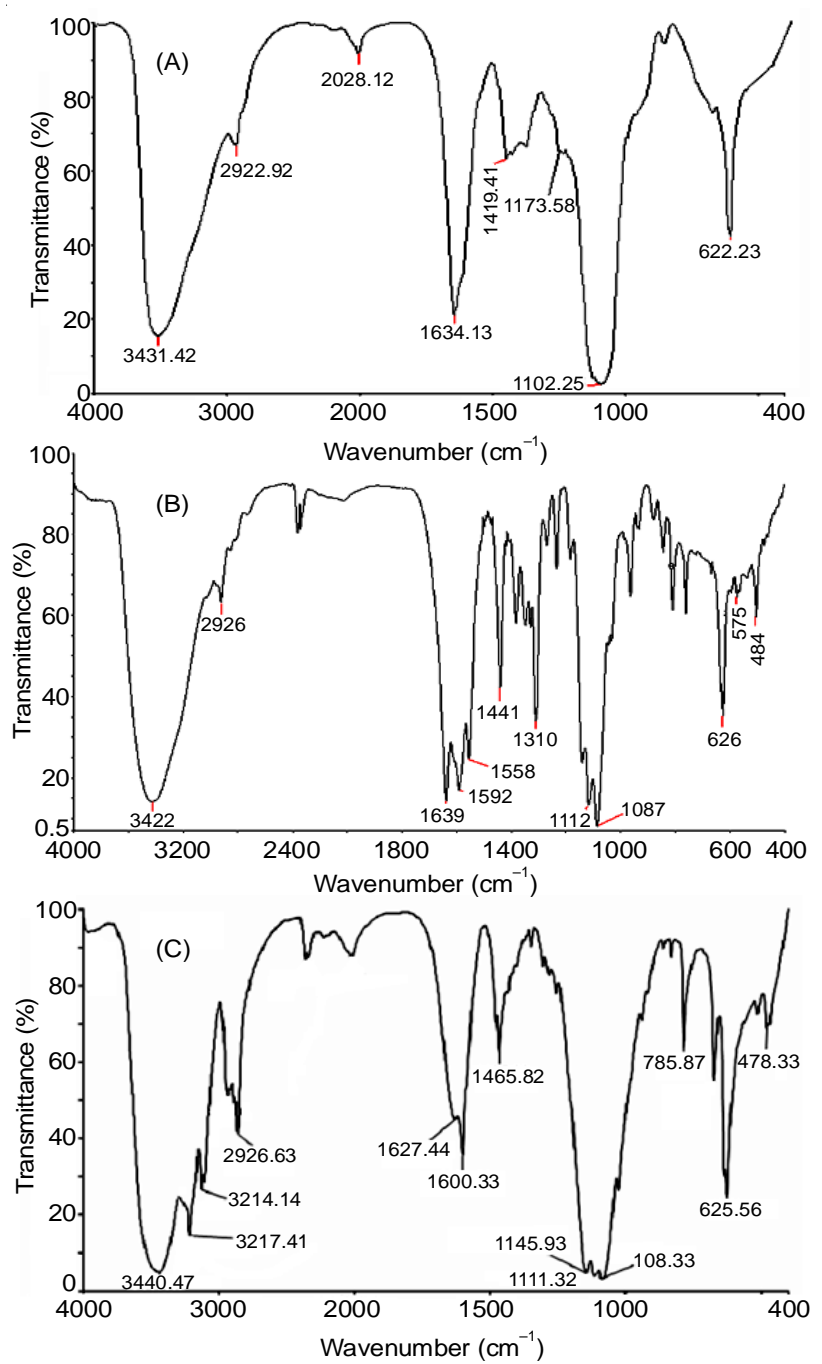

Fig. 1. IR spectra of unsymmetrical binuclear $\mathrm{Cu}$ (II) complex A, B and C

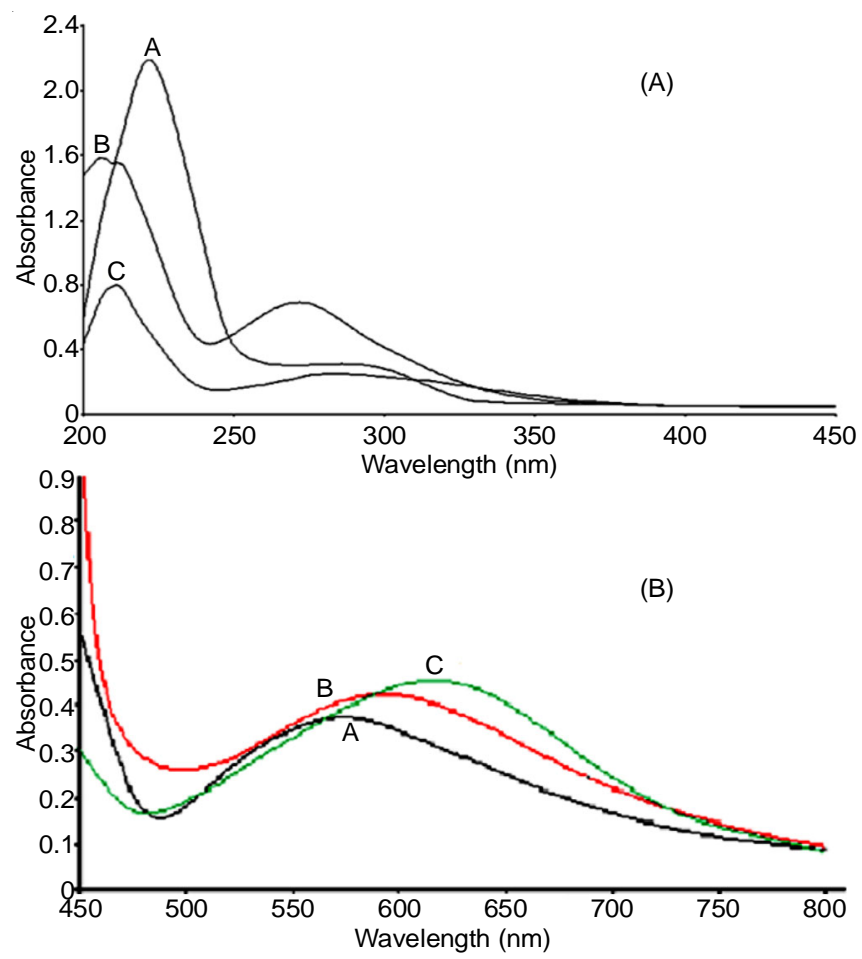

Fig. 2. Electronic absorption spectra of complex A and B
It shows that coordination geometry of complex $\mathbf{A}$ is less distorted than that of the later complexes $\mathbf{B}$ and $\mathbf{C}$. An escalation in $\lambda_{\max }$ (red shift) of $d$ - $d$ transition of metal ion was perceived, which specifies the distortion of coordination geometry as the metal ion increases.

Mass analysis: The ESI mass spectra were done for all the three binuclear $\mathrm{Cu}$ (II) complexes. The ESI mass spectrum of binuclear copper complexes is well illustrated in Fig. 3. The peak at $m / z$ 882(A), 910 (B) and 980 (C) correspond to $\left[\mathrm{M}-2 \mathrm{ClO}_{4}^{-}\right]^{2+}$ ion peak. The ESI mass spectral data of copper (II) complexes confirms the anticipated formula of the complexes.

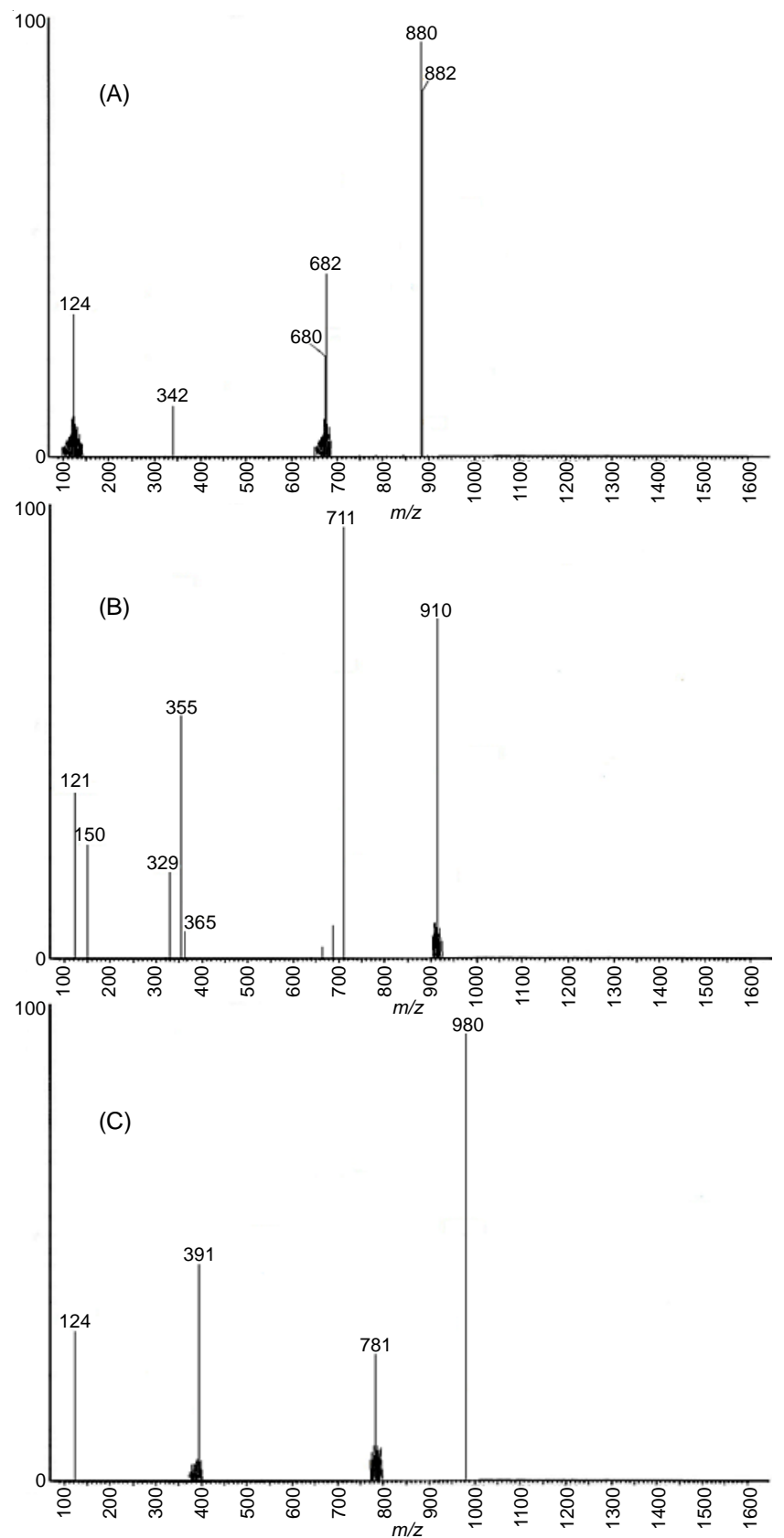

Fig. 3. ESI Mass spectra of unsymmetrical binuclear $\mathrm{Cu}(\mathrm{II})$ complex A, B and $\mathrm{C}$

in vitro Cytotoxicity in $\mathbf{A 5 4 9}$ cell line: The $\mathrm{IC}_{50}$ values of binuclear copper complexes were determined, where complex A exhibited an $\mathrm{IC}_{50}$ value of $15.7 \mu \mathrm{M}$, complex B 8.65 $\mu \mathrm{M}$ and complex $\mathbf{C} 4.58 \mu \mathrm{M}$. Considering the $\mathrm{IC}_{50}$ values, it is evident 
that out of three binuclear copper complexes tested, complex $\mathbf{C}$ is considered to be more effective in exhibiting cytotoxic effect on A549 lung carcinoma cells. Cytotoxic activity of copper complexes is generally attributed to the generation of reactive oxygen species (ROS) by copper ions.

\section{Conclusion}

In the present study, we attempted to prepare an unique "Side-off" binuclear unsymmetrical schiff based copper complexes and the structure of these complexes were characterized and determined by the optical physical probes and also evaluated for their biological (cytotoxic) activity on A549 lung carcinoma cell line. Out of the three complexes tested, complex C exhibited appreciable cytotoxic activity on this cell line.

\section{ACKNOWLEDGEMENTS}

The authors are thankful to Prof. T.N. Sathya, International Institute of Biotechnology and Toxicology, Padappai, India for analyzing the cytotoxic activity of the complexes.

\section{CONFLICT OF INTEREST}

The authors declare that there is no conflict of interests regarding the publication of this article.

\section{REFERENCES}

1. G.G. Mohamed, M.M. Omar and A.M. Indy, Turk. J. Chem., 30, 361 (2006).

2. T. Shu, L. Su, S.-F. Zhou, K.A. Al-Ghanim, S. Mahboob, B. Fugetsu and X. Zhang, Am. J. Biomed. Sci., 7, 205 (2015); doi: 10.5099/aj150400205

3. K.L. Haas and K.J. Franz, Chem Rev., 109, 4921 (2009); https://doi.org/10.1021/cr900134a.

4. C. Marzano, M. Pellei, F. Tisato and C. Santini, Anticancer Agents Med. Chem., 9, 185 (2009); https://doi.org/10.2174/187152009787313837.

5. M. Plotek, K. Dudek and A. Kyziolmarzano, Chemik, 67, 1181 (2013).

6. F. Tisato, C. Marzano, M. Porchia, M. Pellei and C. Santini, Med. Res. Rev., 30, 708 (2010); https://doi.org/10.1002/med.20174.

7. Z.J. Guo and P.J. Sadler, Angew. Chem. Int. Ed., 38, 1512 (1999); https://doi.org/10.1002/(SICI)1521-3773(19990601)38:11<1512:: AID-ANIE1512>3.0.CO;2-Y.

8. T. Storr, K.H. Thompson and C. Orvig, Chem. Soc. Rev., 35, 534 (2006); https://doi.org/10.1039/b514859f.
9. T.W. Hambley, Science, 318, 1392 (2007); https://doi.org/10.1126/science.1150504.

10. S.H. van Rijt and P.J. Sadler, Drug Discov. Today, 14, 1089 (2009); https://doi.org/10.1016/j.drudis.2009.09.003.

11. S.J. Berners-Price, R.K. Johnson, C.K. Mirabelli, L.F. Faucette, F.L. McCabe and P.J. Sadler, Inorg. Chem., 26, 3383 (1987); https://doi.org/10.1021/ic00267a034.

12. C. Marzano, V. Gandin, M. Pellei, D. Colavito, G. Papini, G.G. Lobbia, E. Del Giudice, M. Porchia, F. Tisato and C. Santini, J. Med. Chem., 51, 798 (2008); https://doi.org/10.1021/jm701146c.

13. V. Gandin, M. Pellei, F. Tisato, M. Porchia, C. Santini and C. Marzano, J. Cell. Mol. Med., 16, 142 (2012); https://doi.org/10.1111/j.1582-4934.2011.01292.x.

14. C. Marzano, M. Pellei, S. Alidori, A. Brossa, G.G. Lobbia, F. Tisato and C. Santini, J. Inorg. Biochem., 100, 299 (2006); https://doi.org/10.1016/j.jinorgbio.2005.11.014.

15. T. Mosmann, J. Immunol. Methods, 65, 55 (1983); https://doi.org/10.1016/0022-1759(83)90303-4.

16. B.S. Creaven, B. Duff, D.A. Egan, K. Kavanagh, G. Rosair, V.R. Thangella and M. Walsh, Inorg. Chim. Acta, 363, 4048 (2010); https://doi.org/10.1016/j.ica.2010.08.009.

17. D. Senthil Raja, N.S.P. Bhuvanesh and K. Natarajan, J. Biol. Inorg. Chem., 17, 223 (2012); https://doi.org/10.1007/s00775-011-0844-1.

18. S. Tabassum, S. Amir, F. Arjmand, C. Pettinari, F. Marchetti, N. Masciocchi, G. Lupidi and R. Pettinari, Eur. J. Med. Chem., 60, 216 (2013); https://doi.org/10.1016/j.ejmech.2012.08.019.

19. K. Abdi, H. Hadadzadeh, M. Weil and M. Salimi, Polyhedron, 31, 638 (2012); https://doi.org/10.1016/j.poly.2011.10.028.

20. K. Ghosh, P. Kumar, N. Tyagi, U.P. Singh, N. Goel, A. Chakraborty, P. Roy and M.C. Baratto, Polyhedron, 30, 2667 (2011); https://doi.org/10.1016/j.poly.2011.07.019.

21. S. Roy, S. Saha, R. Majumdar, R.R. Dighe and A.R. Chakravarty, Polyhedron, 29, 2787 (2010); https://doi.org/10.1016/j.poly.2010.06.028.

22. V.M. Manikandamathavan and B. Unni Nair, Eur. J. Med. Chem., 68, 244 (2013); https://doi.org/10.1016/j.ejmech.2013.07.051.

23. L. Wang, K. Zheng, Y. Li, Z. Wu and C. Yan, J. Mol. Struct., 1037, 15 (2013); https://doi.org/10.1016/j.molstruc.2012.11.035.

24. X. Qiao, Z. Ma, C. Xie, F. Xue, Y.-W. Zhang, J.-Y. Xu, Z.-Y. Qiang, J.S. Lou, G.-J. Chen and S.-P. Yan, J. Inorg. Biochem., 105, 728 (2011); https://doi.org/10.1016/j.jinorgbio.2011.01.004.

25. G. Jaouen, Organometallics Targeted to Specific Biological Sites: The Development of New Therapies. Bioorganometallics: Biomolecules, Labeling, Medicine. Wiley-VCH: Weinheim, Chap. 3 (2006). 